\title{
PERSEPSI DAN SIKAP TERHADAP KEPUTUSAN PEMBELIAN PRODUK PANGAN FUNGSIONAL PADA GENERASI MILENIAL
}

\author{
DEWI NUSRANINGRUM ${ }^{1}$ \\ TRI MAYANG MEKAR ${ }^{2}$ \\ SEKAR WULAN PRASETYANINGTYAS ${ }^{3}$
}

\author{
${ }^{1}$ Program Pasca Sarjana Universitas Mercu Buana, Jl. Raya, Meruya Sel., Kembangan, Jakarta, Indonesia \\ ${ }^{2}$ Fakultas Ekonomi dan Bisnis Universitas Mercu Buana, Jl. Raya, Meruya Sel., Kembangan, Jakarta, Indonesia \\ ${ }^{3}$ BINUS Business School, Joseph Wibowo Center Hang Lekir I No. 6, Senayan Jakarta, Indonesia \\ dewi.nusraningrum@mercubuana.ac.id, tri.mayang@mercubuana.ac.id, sekar.p@binus.edu
}

\begin{abstract}
Functional food consumption is one of the trends in the World food market industry, along with increasing public awareness for healthy living. But the market share of functional food is still very small when compared to the food and beverage market as a whole. The study aims to determine how the perception and attitude of millennials influence the consumption of functional food. Data retrieval is done by using online poll to 110 respondents aged 13 to 32 years residing in the area of Jakarta, Bogor, Depok and Tangerang. Data analysis techniques using Structural Equation Modeling. Testing proved that the consumer perception of millennials gave a positive and significant influence on the purchasing decisions of functional food. Millennials have the perception that functional food is attractive, and in the act, they want functional food to be a part of consumption. By knowing how perception and attitude influence purchasing decisions, it is hoped to help the industry to devise the right business strategy.
\end{abstract}

Keywords: Functional food, millenials generation, perception, attitude

\begin{abstract}
Abstrak: Konsumsi pangan fungsional merupakan salah satu tren di industri pasar pangan dunia, seiring dengan semakin meningkatnya kesadaran masyarakat untuk hidup sehat. Namun pangsa pasar pangan fungsional masih sangat kecil jika dibandingkan dengan pasar makanan dan minuman secara keseluruhan.Penelitian ini bertujuan untuk mengetahui bagaimana pengaruh persepsi dan sikap generasi milenial terhadap konsumsi pangan fungsional. Pengambilan data dilakukan dengan melalui pengisian angket secara terhadap 110 responden berusia 13 hingga 32 tahun yang berdomisili di wilayah Jakarta, Bogor, Depok dan Tangerang.Teknikanalisis data menggunakan Structural Equation Modelin.Pengujian membuktikan bahwa persepsi konsumen generasi milenial memberikan pengaruh positif dan signifikan terhadap keputusan pembelian pangan fungsional. Generasi milenial mempunyai persepsi bahwa pangan fungsional berpenampilan menarik, dan dalam bersikap, mereka menginginkan pangan fungsional menjadi bagian dari konsumsi.Dengan mengetahui bagaimana persepsi dan sikap mempengaruhi keputusan pembelian, diharapkan dapat membantu industry untuk menyusun strategi bisnis yang tepat.
\end{abstract}

Kata kunci: Pangan fungsional, generasi milenial, persepsi, sikap 


\section{PENDAHULUAN}

Tumbuhnya industri pangan fungsional merupakan salah satu tren di industri pasar pangan dunia. Hal ini seiring dengan semakin meningkatnya kesadaran masyarakat untuk hidup sehat. Namun pangsa pasar pangan fungsional masih sangat kecil jika dibandingkan dengan pasar makanan dan minuman secara keseluruhan. Hal ini tidak hanya terjadi di pasar dunia, tetapi juga di Indonesia. Perkembangan pangan fungsional baik dari segi konsumsi maupun produk menunjukkan kecenderungan peningkatan. Hal ini sejalan dengan kesadaran konsumen untuk makan makanan sehat, dan keinginan untuk mencegah penyakit dari usia muda. Tetapi bila dibandingkan dengan pasar makanan dan minuman secara umum, porsi konsumsi pangan fungsional masih kecil. Generasi milenial merupakan generasi yang terbanyak di Indonesia. Dari sisi perilaku sebagai konsumen, generasi ini sangat penting karena preferensi dan sikap konsumsi mereka saat ini akan mempengaruhi pola konsumsi mereka selanjutnya. Di Indonesia, penelitian tentang kaitan perilaku konsumsi generasi milenial terhadap pangan fungsional, masih sedikit.

Pangan fungsional, secara umum, adalah pangan yang tidak hanya memberikan zat-zat gizi esensial pada tubuh, tetapi juga memberikan efek perlindungan tubuh atau bahkan efek penyembuhan terhadap beberapa gangguan penyakit. Pangan fungsional semakin digemari terutama didasari semakin banyaknya penyakit yang muncul yang bersumber dari pola makan, bahkan gejala penyakit tesebut sudah dimulai pada usia muda. Hasil penelitian sebelumnya menunjukkan bahwa milenial memilih pangan fungsional dengan alas an kesehatan dan rasanya yang memenuhi selera (Amaliah, 2018).
Perilaku pembelian setiap orang merupakan perilaku yang unik, karena preferensi dan sikap terhadap obyek setiap orang berbeda. Terdapat beberapa segmen konsumen, sehingga apa yang diinginkan dan dibutuhkan oleh setiap orang juga berbeda. Generasi Milenial yang merupakan populasi terbesar saat ini, memiliki kebutuhan dan keinginan yang berbeda. Banyak faktor yang mempengaruhi keputusan pembelian. Untuk meningkatkan konsumsi produk pangan fungsional, perlu dipahami perilaku konsumen terhadap produk atau merek yang beredar di pasar, dan untuk selanjutnya, perlu dilakukan berbagai cara untuk membuat konsumen tertarik terhadap produk pangan fungsional tersebut.

\section{Persepsi}

Perilaku konsumen berdasarkan Kanuk dan Schiffman (2010) didefinisikan sebagai "perilaku yang diperlihatkan konsumen dalam mencari, membeli, menggunakan, mengevaluasi, dan menghabiskan produk dan jasa yang mereka harapkan akan memuaskan kebutuhan mereka". Sedangkan Suwarman (2010) menyimpulkan perilaku konsumen sebagai "semua kegiatan, tindakan, serta proses psikologis yang mendorong tindakan tersebut pada saat sebelum membeli, menggunakan, menghabiskan produk dan jasa setelah melakukan hal-hal di atas atau kegiatan mengevaluasi."

Kotler dan Amstrong (2016) mengatakan terdapat beberapa faktor yang mempengaruhi perilaku konsumen, yaitu: Faktor budaya merupakan faktor dasar yang mempengaruhi keinginan dan perilaku seseorang. Bagaimana seorang anak dibesarkan dalam sebuah budaya, akan mempengaruhi perilaku pembeliannya. Setiap kelompok budaya dapat berbeda dengan kelompok budaya lainnya. 
Faktor sub-budaya yang memiliki identifikasi dan sosialisasi yang khas pada setiap anggota sub-budaya tersebut, termasuk bangsa, agama, ras dan wilayah geografis sebagai "pembedaan kelompok budaya yang ada sebagai segmen yang tidak dapat diidentifikasikan dalam masyarakat yang kompleks dan lebih besar". Faktor sosial seperti kelompok referensi, keluarga, peran sosial dan status, juga mempengaruhi perilaku konsumen. Kelompok referensi terdiri dari semua kelompok yang secara langsung ataupun tidak langsung dapat mempengaruhi sikap atau perilaku seorang konsumen. keanggotaan adalah kelompok yang secara langsung mempunyai pengaruh terhadap konsumen. Beberapa membership group utama adalah keluarga, teman, tetangga dan rekan kerja. Membership group yang berikutnya adalah rekan sesama profesi dan serikat pekerja. Kelompok referensi memberikan pengaruh berupa perilaku yang baru, gaya hidup, sikap dan konsep diri, serta menciptakan tekanan untuk menyesuaikan pemilihan produk atau nama dagang. Keluarga merupakan kelompok sosial yang paling penting dalam suatu masyarakat, dan telah banyak penelitian tentang hal ini. Orientasi keluarga dalam hal ini terdiri dari orang tua dan kakak/adik. Melalui orangtua, seorang anak memiliki orientasi terhadap agama, politik, dan keadaan ekonomi, termasuk juga ambisi pribadi, kepercayaang diri dan cinta. Anggota keluarga seringkali menjadi faktor yang paling berpengaruh terhadap perilaku sesorang. Peran dan Status merupakan posisi seseorang dalam kelompok, seperti keluarga, klub atau organisasi. Peran terdiri dari aktifitas yang diharapkan dilakukan oleh orang tersebut, dan masing-masing peran digambarkan sebagai status. Perilaku pembelian seseorang dalam memilih produk dapat menyatakan atau memperlihatkan peran dan status mereka di masyarakat.

Faktor Personal. Umur dan Tahap

Siklus Hidup. Seseorang selalu membeli produk dan jasa yang berbeda sepanjang hidupnya. Mereka mengkonsumsi makanan bayi pada saat masih kecil, dan sebagian besar makanan ketika tumbuh dan menjadi dewasa, serta makanan khusus di saat usia senja. Selera akan pakaian, perabotan dan juga rekreasi berbeda tergantung dari usianya. Pekerjaan dan Keadaan Ekonomi. Pola atau kebiasaan konsumsi juga dipengaruhi oleh pekerjaan seseorang. Pemasar harus dapat mengidentifikasi kelompok pekerja mana yang sesuai dengan produk dan jasa yang ditawarkan. Kemampuan seseorang untuk membelanjakan uangnya, juga mempengaruhi pilihan produk.

Konsep diri menggambarkan aspek yang paling penting dari seluruh kepribadian seseorang (Nusraningrum 2012) yang akan mempengaruhi perilakunya dalam membeli produk atau jasa karena merupakan karakter psikologis yang bersifat unik, dan bersifat relatif konstan terhadap lingkungannya. Gaya Hidup adalah pola hidup seseorang yang diterjemahkan kedalam aktifitas, minat dan pendapatnya, sehingga gaya hidup ini merupakan potret interaksi seseorang dengan lingkungannya.

Faktor Psikologis. Motivasi merupakan dorongan dalam diri seseorang yang akan menghasilkan suatu bentuk tindakan. Dorongan ini biasanya muncul karena adanya keinginan atau kebutuhan yang belum terpenuhi. Dari berbagai keinginan-keinginan yang ada, tidak semuanya dapat diarahkan untuk kepentingan lain selain keinginannya sendiri. Motivasi di sini berfungsi untuk mengarahkannya. Sebagai proses psikologis, motivasi mencerminkan interkasi antar sikap, persepsi, kebutuhan, dan keputusan. Persepsi merupakan suatu proses dimana seseorang melakukan pemilihan, pengorganisasian, dan mengartikan masukan informasi untuk menciptakan suatu gambaran tentang kehidupan. Pembelajaran. Ketika seseorang bertindak, maka orang tersebut juga belajar. Dari pembelajaran dapat terjadi perubahan yang merupakan hasil dari pengalaman. 
Pembelajaran terdiri dari tahapan-tahapan seperti dorongan dari rangsangan, tanda-tanda atau isyarat, tanggapan. dan penguatan (reinforcement). Dorongan rangsangan dalam diri seseorang akan membuat orang tersebut melakukan tindakan. Isyarat adalah rangsangan kecil yang menentukan kapan, dimana dan bagaimana seseorang memberikan tanggapan. Dalam pandangan pemasaran, pembelajaran diartikan sebagai proses ketika seseorang mendapatkan pengetahuan dan pengarahan yang diterapkan untuk perilaku selanjutnya. Keyakinan dan Sikap. Melalui tindakan dan pembelajaran, seseorang mendapatkan keyakinan dan sikap yang akan mempengaruhi perilaku konsumsi. Keyakinan dapat didasarkan pada pengetahuan, pendapat atau keberuntungan, dan semua itu dapat mempengaruhi keputusan pembelian produk. Sikap juga sama pentingnya karena akan menunjukan apakah produk tersebut disukai atau tidak.

\section{Proses Keputusan Konsumen}

Keputusan pembelian adalah keputusan sebagai pemilik tindakan dari dua pilihan atau lebih (Schiffman \& Kanuk, 2008) dimana setiap orang harus mempertimbangkan sesuatu sebelum melakukan pembelian (Nusraningrum et.al. (2019). Model Keputusan Konsumen terdiri dari beberapa tahap, yaitu pengenalan kebutuhan, pencarian informasi, evaluasi alternatif, pembelian, dan kepuasan konsumen (Sumarwan, 2014). Proses keputusan konsumen tersebut dipengaruhi tiga faktor utama, yaitu: strategi pemasaran, perbedaan individu, dan faktor lingkungan. Pengenalan kebutuhan muncul ketika konsumen menghadapi suatu masalah, yaitu suatu keadaan dimana terdapat perbedaan antara keadaan yang diinginkan dengan keadaan yang sebenarnya terjadi. Pencarian informasi dimulai ketika konsumen merasa ada kebutuhan, dan kebutuhan tersebut dapat dipenuhi dengan membeli dan mengkonsumsi suatu produk. Informasi dapat bersifat internal (informasi yang sudah tersimpan di dalam ingatannya), atau eksternal (mencari informasi dari luar).

Tahap berikutnya adalah evaluasi alternatif. Pada tahapan ini, konsumen akan memproses dan mengevaluasi pilihan produk dan merek, serta memilihnya sesuai keinginan konsumen. Di sini konsumen akan membandingkan berbagai pilihan produk yang dianggap dapat memenuhi keinginannya. Jika konsumen telah memutuskan alternatif yang dipilih dan kemungkinan penggantinya jika diperlukan, maka konsumen akan melakukan pembelian. Pembelian meliputi keputusan konsumen tentang apa yang dibeli, apakah membeli atau tidak, kapan membeli, dimana membeli, dan bagaimana cara membayarnya. Tahap keempat dari proses keputusan adalah konsumsi atau penggunaan produk.

Di dalam suatu proses keputusan, konsumen tidak akan berhenti pada tahap ini saja. Konsumen akan melakukan evaluasi terhadap produk yang telah dikonsumsi sebelumnya. Inilah yang disebut evaluasi alternatif paska pembelian atau paska konsumsi. Proses ini disebut juga proses evaluasi alternatif tahap kedua. Setelah mengkonsumsi produk, maka konsumen akan memiliki perasaan puas atau tidak puas terhadap barang dikonsumsinya. Adanya perasaan puas membuat konsumen akan membeli dan mengkonsumsi ulang produk tersebut.

\section{Pangan Fungsional}

Semua makanan pada dasarnya memiliki fungsi, karena makanan tersebut memiliki rasa, aroma dan nilai nutrisi. Hippocrates lebih dari 2500 tahun yang lalu sudah mengatakan "Let food be the medicine and medicine be thy food". Di tahun 1900an, peran penting dari "diet" (pengaturan makanan) dalam pencegahan penyakit dan menjaga kesehatan lebih mengedepan lagi. Apakah 
pangan fungsional? Secara universal, tidak ada definisi yang diterima di seluruh dunia. Konsep pangan fungsional pertama kali berkembang di Jepang. Pada tahun 1984, pemerintah Jepang mengalokasi dana penelitian untuk mempelajari pangan fungsional atau disebut juga Foods for Specific Health Uses (FOSHU) (Martirosyan \& Singh, 2015). Di Amerika Serikat, berdasarkan FFC (Functional Food Center), pangan fungsional adalah "Natural or processed foods that contains known or unknown biologicallyactive compounds: which, in defined, effective non-toxic amounts, provide a clinically proven and documented health benefit for the prevention, management, or treatment of chronic disease". Di Uni Eropa, belum ada kesepakatan formal tentang definisi pangan fungsional.

Di Indonesia definisi dari pangan fungsional adalah pangan olahan yang mengandung satu atau lebih komponen pangan yang berdasarkan kajian ilmiah mempunyai fungsi fisiologis tertentu di luar fungsi dasarnya, terbukti tidak membahayakan dan bermanfaat bagi kesehatan (Perka BPOM, 2011). Komponen pangan fungsional dikelompokan dalam lima belas kelompok (Perka BPOM, 2005), antara lain: Vitamin, Mineral, Serat Pangan, Prebiotik, Probiotik, Kolin, Isoflavin dan Polifenol (teh). Dalam peraturan BPOM tersebut juga diatur tentang klaim yang diizinkan berkenaan dengan setiap komponen funsionalnya. Klaim tersebut dapat dibagi menjadi:

1) Klaim gizi (klaim kandungan zat gizi dan klaim perbandingan zat gizi)

2) Klaim kesehatan (klaim fungsi zat gizi, klaim fungsi lain, klaim penurunan resiko penyakit)

3) Klaim indeks glikemiks yang harus dibuktikan dengan uji klinis.

Pasar pangan fungsional diperkirakan akan tumbuh sebesar 25\% di tahun 2017 (Bonar, 2014) sehingga mencapai angka USD 54 Milyard. Pasar Amerika Serikat akan tumbuh paling cepat, mengungguli pasar yang sebelumnya dikuasai oleh Jepang. Nielsen (2015) melakukan survei di 60 negara, termasuk Indonesia dengan responden sebanyak 30.000 , ternyata atribut yang paling popular untuk pangan funsional adalah "backto-basics foods" atau pangan yang alamiah, seperti konsep alamiah / natural, bebas GMO (Genetically Modified Foods), tidak ada perasa atau pewarna buatan, dibuat dari sayuran atau buah. Triyanti (2016) menyatakan bahwa dari perspektif industri, kecenderungan perkembangan pasar pangan fungsional mengarah ke produk-produk yang sehat dan menarik; mempertimbangkan masukan gula, sodium, lemak dan kolesterol; serta kebutuhan akan lebih banyak serat dan protein.

\section{Generasi Milenial}

Setiap generasi pada zamannya memiliki ciri dan karakteritik masing-masing. Di dalamnya ada kesamaan ataupun perbedaan yang dapat dijadikan gambaran umum atas bagaimana mereka berperilaku. Salah satu generasi yang paling mencolok adalah generasi milenial karena generasi ini sangat beragam. Senappen dan Gualtieri (2012) menyebutkan bahwa individu yang dilahirkan antara tahun 1980 hingga 1999 dapat dikelompokan dalam Generasi Milenial atau Generasi $Y$ atau Next Generation atau Echo Boomers. Generasi ini pada tahun 2010, mencakup umur 13 hingga 32 tahun. Pasar kelompok ini terkadang digolongkan juga sebagai remaja yang lebih tua dan dewasa muda. Berdasarkan Statistik Indonesia (2010), generasi milenial mewakili lebih dari 35\% penduduk Indonesia, yang artinya merupakan pasar yang cukup besar. Dinamika pasar ini juga sangat beragam. Pasar remaja dan dewasa muda merupakan pasar yang menarik untuk dua hal. Pertama, preferensi dan selera yang terbentuk selama kurun waktu ini, dapat mempengaruhi perilaku konsumsi mereka sepanjang waktu. Kedua, kelompok ini mempunyai kemampuan membeli yang besar untuk konsumsi personalnya. Dari 
survei Nielsen (2015) sebanyak 33\% generasi milenial mengangap klaim pangan sehat merupakan klaim yang sangat penting. Generasi ini juga mau membayar lebih untuk premium produk pangan fungsional. Dibandingkan dengan generasi lainnya, generasi milenial yang tertinggi.

Suatu penelitian yang dilakukan terhadap konsumen mahasiswa menunjukkan bahwa kesadaran mahasiswa perguruan tinggi terhadap pangan fungsional masih kurang, dan mereka juga masih meragukan kegunaan dari pangan fungsional terhadap kesehatan diri (Bilgic \& Yuksel 2012). Penelitian lain yang dilakukan di kalangan mahasiswa di Indonesia juga menyimpulkan bahwa terdapat hubungan antara persepsi tentang pangan sehat dengan alasan pemilihan pangan berupa kesehatan, suasana hati, kandungan alami dalam pangan, pengendalian berat badan, dan masalah etika dengan kebiasaan makan (Puspadewi \& Briawan 2014).

$\mathrm{H}_{1}$ : Terdapat pengaruh antara persepsi dengan keputusan pembelian.

$\mathrm{H}_{2}$ : terdapat pengaruh antara sikap dengan keputusan pembelian.

\section{METODE PENELITIAN}

Penelitian ini menggunakan pendekatan kuantitatif dengan menyebarkan kuesioner secara online. Variabel yang digunakan adalah persepsi, sikap dan keputusan pembelian produkpanganfungsional yang diuraikan dalam indikator dan selanjutnya diturunkan menjadi item pertanyaan dalam instrumen penelitian.

Definisi Operasional dan Pengukuran Variabel

a. Persepsi adalah proses diolahnya informasi menggunakan indera penciuman, pendengaran, penglihatan, perabaan dan perasaan (Slameto, 2010).

b. Sikap adalah perasaan mendukung atau memihak (Rahayuningsih, 2008).

c. Keputusan pembelian adalah keputusan pembelian terhadap produk yang mau dibeli (Nusraningrum et.al.,2019).

Teknik analisis data menggunakan Structural Equation Modeling - Partial Least Square, dilakukan untuk menjelaskan secara menyeluruh hubungan antar variabel yang memungkinkan pengujian sebuah rangkaian hubungan secara simultan.

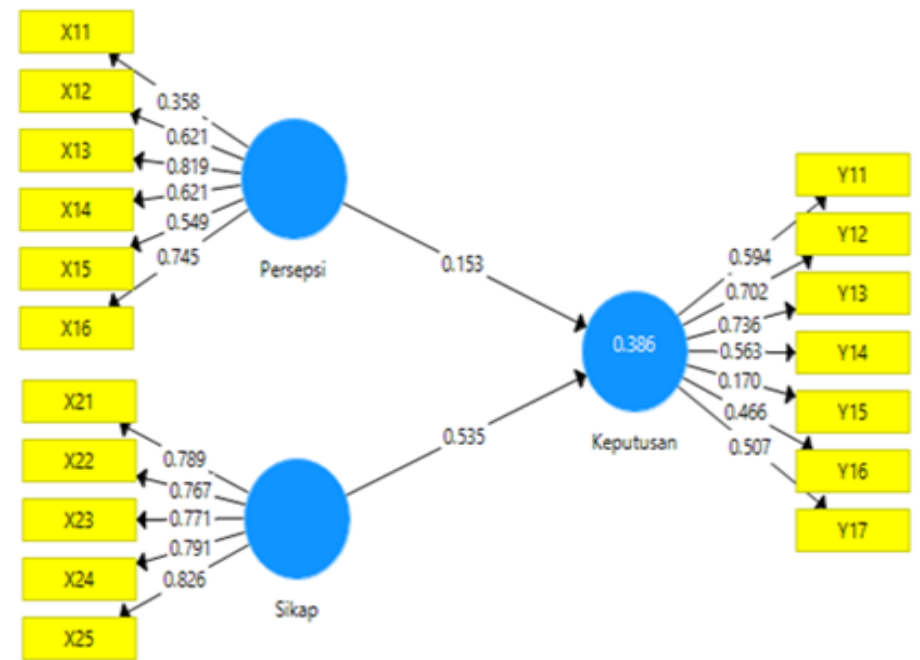

Gambar 1 Model Penelitian 


\section{HASIL}

Tabel 1 RespondenPenelitian

\begin{tabular}{|c|c|c|c|}
\hline & Uraian & Total & $\%$ \\
\hline \multirow{4}{*}{$\frac{\pi}{\mathscr{D}}$} & $15-19$ & 24 & 21.8 \\
\hline & $20-24$ & 38 & 34.5 \\
\hline & $25-29$ & 26 & 23.6 \\
\hline & $30-34$ & 12 & 10.9 \\
\hline \multirow{2}{*}{ 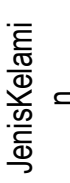 } & Pria & 65 & 59.1 \\
\hline & Wanita & 45 & 40.9 \\
\hline \multirow{5}{*}{$\begin{array}{l}\frac{c}{\mathbb{D}} \\
\frac{\mathbb{0}}{\bar{D}} \\
\frac{\vec{d}}{d} \\
\square\end{array}$} & Mahasiswa Diploma/Sarjana & 69 & 62.7 \\
\hline & Mahasiswa Pascasarjana & 13 & 11.8 \\
\hline & Pekerja - Diploma /Sarjana & 18 & 16.4 \\
\hline & Pekerja - Pascasarjana & 6 & 5.5 \\
\hline & Lainnya & 5 & 4.5 \\
\hline
\end{tabular}

Berdasarkan Tabel 1 diketahui bahwa pada kelompok usia terdiri dari 4 kelompok, responden yang memiliki usia 15-19 tahun terdiri dari $21.8 \%, 20-24$ tahun terdiri dari $34.5 \%$, 25-29 tahun terdiri dar i23.6\% dan 30 34 tahun terdiri dari $10.9 \%$. Komposisi terbesar berada dalam kelompok 20 - 24 tahun yang artinya usia yang sedang tumbuh serta proses pencarian bekerja. Bauran jenis kelamin diketahui mayoritas adalah pria $59.1 \%$ dan wanita sebanyak $40.9 \%$. Pada pekerjaan diketahui mayoritas adalah mahasiswa diploma/sarjana sebanyak $62.7 \%$, artinya bahwa pihak yang sedang melakukan proses belajar.

Analisa keputusan pembelian dilakukan dengan pendekatan partial least square. Hal ini ditujukan untuk mengetahui indikator penting yang berperan dalam model (Hair et.al., 2010).

Tabel 2 Uji Validitas

\begin{tabular}{lrcc} 
Indikator & Output & Batasan & Keterangan \\
\hline X11 & 0.358 & 0.5 & Tidak Valid \\
X12 & 0.621 & 0.5 & Valid \\
X13 & 0.819 & 0.5 & Valid \\
X14 & 0.621 & 0.5 & Valid \\
X15 & 0.549 & 0.5 & Valid \\
X16 & 0.745 & 0.5 & Valid \\
X21 & 0.789 & 0.5 & Valid \\
X22 & 0.767 & 0.5 & Valid \\
X23 & 0.771 & 0.5 & Valid \\
X24 & 0.791 & 0.5 & Valid \\
X25 & 0.826 & 0.5 & Valid \\
Y11 & 0.594 & 0.5 & Valid
\end{tabular}




\begin{tabular}{lrrc} 
Y12 & 0.702 & 0.5 & Valid \\
Y13 & 0.736 & 0.5 & Valid \\
Y14 & 0.563 & 0.5 & Valid \\
Y15 & 0.17 & 0.5 & Tidak Valid \\
Y16 & 0.466 & 0.5 & Tidak Valid \\
Y17 & 0.507 & 0.5 & Valid \\
\hline
\end{tabular}

Tabel 2 memberikan informasi bahwa dari 18 indikator yang digunakan dalam penelitian sehingga perlu dikeluarkan dari model yang terdapat 3 variabel yang dinyatakan tidak valid, diteliti.

\begin{tabular}{|c|c|}
\hline Indikator & Output \\
\hline \multicolumn{2}{|l|}{ Konsumsi Pangan fungsional } \\
\hline $\begin{array}{l}\text { menjadi trend pembicaraan yang } \\
\text { menarik belakanganini }(X 12)\end{array}$ & \\
\hline \multirow{2}{*}{\multicolumn{2}{|c|}{$\begin{array}{l}\text { Produk pangan fungsional } \\
\text { mempunvai penampilan vang }\end{array}$}} \\
\hline & \\
\hline menarik (X13) & 0.837 \\
\hline \multirow{2}{*}{\multicolumn{2}{|c|}{$\begin{array}{l}\text { Produk pangan fungsional memiliki } \\
\text { rasa vang enak (X14) }\end{array}$}} \\
\hline & 0.636 \\
\hline \multicolumn{2}{|l|}{$\begin{array}{l}\text { Produk pangan fungsional } \\
\text { mempunyai bau yang menggugah }\end{array}$} \\
\hline selera (X15) & 0.577 \\
\hline $\begin{array}{l}\text { Mengkonsumsi pangan fungsional } \\
\text { menimbulkan perasaan yang }\end{array}$ & \\
\hline menyenangkan (X16) & 0.752 \\
\hline
\end{tabular}

Tabel 3 memberikan informasi bahwa seluruh indikator memiliki memiliki pengaruh terhadap variabel. Indikator produk pangan fungsional mempunyai penampilan yang menarik memiliki kontribusi terbesar yang artinya akan berdampak dalam membangun persepsi dari responden. Selain itu diketahui bahwa indikator produk pangan fungsional mempunyai bau yang menggugah selera memiliki kontribusi terkecil dalam persepsi hal ini menandakan bahwa pemilik usaha perlu memperhatikan hal tersebut agar kontribusi yang diberikan dapat meningkat.

Tabel 4 Loading Factor Indikator Variabel Sikap

\begin{tabular}{lc}
\hline \multicolumn{1}{c}{ Indikator } & Output \\
\hline $\begin{array}{l}\text { Saya memiliki pengetahuan yang } \\
\text { cukup tentang pangan fungsional }\end{array}$ & \\
$\begin{array}{l}\text { (X21) } \\
\text { Saya mengetahui manfaat utama }\end{array}$ & 0.785 \\
dari mengkonsumsi pangan & \\
fungsional (X22) & 0.771
\end{tabular}


Saya merasa senang ketika

mengkonsumsi pangan fungsional

(X23)

0.771

Saya ingin menjadikan pangan

fungsional sebagai bagian dari

konsumsi makanan dan minuman

saya (X24)

Saya memilih untuk mengkonsumsi

pangan fungsional sebagai bagian

dari konsumsi makanan dan

minuman saya (X25)

0.827

Tabel 4 memberikan informasi bahwa seluruh indikator memiliki pengaruh terhadap variable sikap. Indikator Saya memilih untuk mengkonsumsi pangan fungsional sebagai bagian dari konsumsi makanan dan minuman memiliki kontribusi terbesar yang artinya akan berdampak dalam membangun persepsi dari responden. Selain itu diketahui bahwa indikator saya mengetahui manfaat utama dari mengkonsumsi pangan fungsional dan saya merasa senang ketika mengkonsumsi pangan fungsional memiliki kontribusi terkecil dalam persepsi. Hal ini menandakan bahwa pemilik usaha perlu memperhatikan hal tersebut agar kontribusi yang diberikan dapat meningkat.

Tabel 5 Loading Factor Indikator Variabel Keputusan Pembelian Indikator Output

Informasi tentang manfaat pangan fungsional sudah banyak (Y11) 0.598

Konsumsi pangan fungsional sesuai dengan kebutuhan saya (Y12)

Saya mengetahui dimana dan kapan membeli pangan fungsional (Y13)

Saya membeli pangan fungsional di pasar modern (Supermarket, Mini Market)

(Y14)

Sebelum membeli pangan fungsional, saya akan membandingkan beberapa merek (Y17)

Tabel 5 memberikan informasi bahwa seluruh indikator memiliki pengaruh terhadap variable keputusan pembelian. Indikator konsumsi pangan fungsional sesuai dengan kebutuhan saya memiliki kontribusi terbesar yang artinya akan berdampak dalam membangun persepsi dari responden. Selain itu diketahui bahwa indikator Sebelum membeli pangan fungsional, saya akan membandingkan beberapa merek memiliki kontribusi terkecil dalam persepsi hal ini menandakan bahwa pemilik usaha perlu memperhatikan hal tersebut agar kontribusi yang diberikan dapat meningkat. 


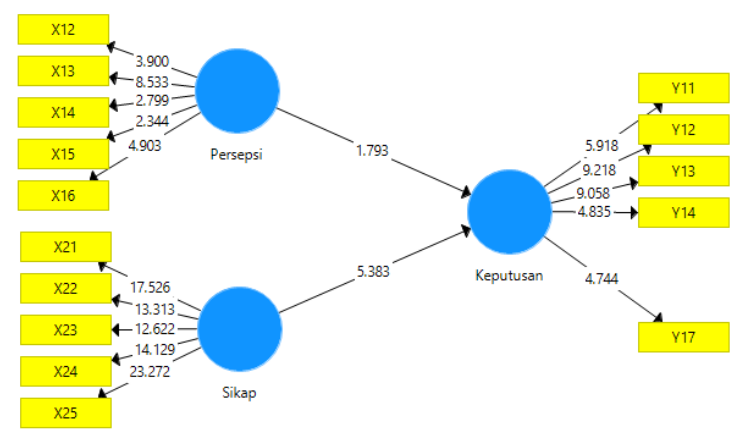

Gambar 3. Uji Hipotesis Penelitian

Tabel 6 Hipotesis Penelitian

\begin{tabular}{|c|c|c|c|}
\hline Hipotesis & Koefisien & $\begin{array}{c}\mathbf{P} \\
\text { Value }\end{array}$ & $\begin{array}{c}\text { Keterangan } \\
(10 \%)\end{array}$ \\
\hline Persepsi --> & & & Positif \& \\
\hline Keputusan & 0.177 & 0.074 & Signifikan \\
\hline Sikap --> & & & Positif \& \\
\hline Keputusan & 0.515 & 0 & Signifikan \\
\hline
\end{tabular}

\section{Pengaruh Persepsi terhadap Keputusan pembelian}

Diketahui bahwa hubungan persepsi memiliki pengaruh positif $(0.177)$ dan signifikan (0.074). Temuan ini menandakan bahwa persepsi dari para konsumen mampu mendorong untuk melakukan pembelian. Pemilik usaha harus mampu membangun persepsi positif dari para konsumen melalui pangan yang trend dan rasa yang enak. Prasetyo et. al. (2018) memberikan penjelasan bahwa persepsi konsumen merupakan hal penting yang harus dibangun agar dapat memberikan dampak terhadap meningkatnya aktifitas pembelian. Wardhani (2015) memberikan penjelasan bahwa persepsi konsumen yang memberikan dampak besar bagi bisnis.

\section{Pengaruh Sikap terhadap Keputusan Pembelian}

Diketahui bahwa hubungan persepsi memiliki pengaruh positif $(0.515)$ dan signifikan (0.000). Temuan ini menandakan bahwa sikap positif dari responden mampu memberikan dampak terhadap keputusan pembelian konsumen. Pemilik usaha perlu mendorong agar sikap konsumen menjadi positif, hal ini dapat didorong melalui indikator mengetahui manfaat utama dari mengkonsumsi pangan fungsional dan senang ketika mengkonsumsi pangan fungsional. Sarwoko dan Churiyahc (2007) sikap konsumen menjadi bagian penting bagi pemilik usaha dalam mengetahui masa depan usaha, sikap positif konsumen mampu mendorong keputusan pembelian. Sumiati (2014) mampu memberikan pandangan bahwa sikap berpengaruh positif terhadap keputusan pembelian, temuan ini disebabkan karena sikap merupakan bentuk reaksi dari konsumen.

\section{PENUTUP}

Deskripsi responden penelitian merupakan hal penting yang mampu memberikan gambaran kondisi dari data. Mayoritas usia responden adalah 20-24 Tahun, dengan jenis kelamin laki-laki dan pekerjaan sebagai mahasiswa diploma atau sarjana.Pengujian membuktikan bahwa persepsi konsumen memberikan pengaruh positif dan signifikan terhadap keputusan pembelian. Selain pada pengujian sikap konsumen menjadi bagian penting yang 
mampu meningkatkan secara signifikan keputusan pembelian.

Para pelaku usaha pangan fungsional harus secara holistik menentukan strategi pemasarannya agar tepat sasaran dengan memperhatikan hal-hal dari persepsi dan sikap generasi milenial ketika menyusun strategi bisnis dalam kerangka meningkatkan keputusan pembelian pada generasi milenial.

\section{REFERENCES:}

Amaliah, Isma. 2018. Persepsi Generasi Milenial terhadap Pangan Fungsional di Indonesia. Undergraduate (S1) thesis, Universitas Bakrie.

Badan Pengawasan Obat dan Makanan 2011. Peraturan tentang Pengawasan Klaim dalam Label dan Iklan Pangan Olahan

Bilgic, S. and A. Yuksel 2012. University Students' Perception and Attitudes toward Functional Foods in Istanbul. Proceeding of the 2012 International Conference on Industrial and Operations Management, Istanbul, Turkey, July 3-6, 2012.

Bonar, A. 2014. Functional foods market. http://www.nutraingredients.com/Markets-and-Trends/Functional-foodsmarket-is-expected-to-grow-25-by-2017-Leatherhead.

Hair JF, Black WC, Babin BJ.2009. Multivariate data analysis (7th ed.). Upper Saddle River: Prentice Hall.

Kotler, P. and K.L. Keller 2016. A Framework for Marketing Management. $6^{\text {th }}$ Edition. Global Edition. Pearson.

Martirosyan, D.M. and J. Singh 2015. A new definition of functional food by FFC: what makes a new definition unique? Functional Foods in Health and Disease 2015; 5(6): 209-223.

Nielsen, A.C. 2015. We are what we eat. Survey Result.

Nusraningrum, Dewi. 2012. The Relationship Between Self-Concept and Aircraft Technician Performance. World Review of Business Research Vol. 2. No. 6. Pp. $69-83$.

Nusraningrum, Dewi, Pangestu PR., Alaydrus LL. 2019. Web-Based Ticket's Purchase. International Journal of Recent Technology and Engineering (IJRTE). ISSN: 2277-3878, Volume-8 Issue-2S. pp. 326-333.

Palupi, N.S. 2013. Pangan Fungsional dalam Pola Konsumsi Pangan untuk Hidup Sehat, Aktif dan Produktif. Disampaikan pada "Kegiatan Apresiasi Pengembangan Pola Konsumsi Pangan, Bogor, 21-23 Maret 2013.

Puspadewi, R.N. dan D. Briawan 2014. Persepsi tentang Pangan Sehat, Alasan Pemilihan Pangan dan Kebiasaan Makan Sehat pada Mahasiswa. J. Gizi Pangan, 9(3), November, 211-218.

Sumiati. 2014. Pengaruh Motivasi Konsumen, Persepsi Kualitas, Sikap Konsumen, dan Brand Image Pada Keputusan Pembelian Komputer Tablet Apple Ipad Pada Emax Apple Store Surabaya. Jurnal IImu Ekonomi \& Manajemen. 1(2), 110-123.

Sugiyono. 2010. Metode Penelitian Pendidikan Pendekatan Kuantitatif, kualitatif, dan R\&D. Bandung: Alfabeta.

Sarwoko E, Churiya M. 2007. Pengaruh Sikap Konsumen Terhadap Keputusan Pembelian Minuman Merek Aqua Berkaitan dengan Penerapan Program CSR (Corporate Social Responsibility). Jurnal Ekonomi Modernisasl. 3(2), $147-164$.

Schiffman, L. dan L.L. Kanuk 2008. Perilaku Konsumen. Edisi Ketujuh. Indeks.

Seppanen, S. and W. Gualtieri 2012. The Millennial Generartion. Research Review. NCF. National Chamber Foundation.

Sumarwan, U. 2015. Perilaku Konsumen: Teori dan Penerapannya dalam Pemasaran. Edisi Kedua. Ghalia Indonesia.

Sumiati. 2014. Pengaruh Motivasi Konsumen, Persepsi Kualitas, Sikap Konsumen, dan Brand Image Pada Keputusan Pembelian Komputer Tablet Apple Ipad Pada Emax Apple Store Surabaya. Jurnal IImu Ekonomi \& Manajemen. 1(2) : 110-123.

Sugiyono. 2010. Metode Penelitian Pendidikan Pendekatan Kuantitatif, kualitatif, dan R\&D. Bandung: Alfabeta. 
Triyanti, I. 2016. Functional Food: Challenges and Opportunities from Industrial Perspective. Kuliah Umum di Fakultas Teknologi Industri Pertanian Universitas Padjadjaran, Bandung, 1 April 2016.

Prasetyo AY, Fauzi ADH, Sanawiri B. 2018. Pengaruh persepsi terhadap keputusan pembelian (survei pada mahasiswa s1 program studi ilmu administrasi bisnis angkatan 2014/2015, 2015/2016, dan 2016/2017 fakultas ilmu administrasi universitas brawijaya yang membeli dan menggunakan sepatu converse).Jurnal administrasi bisnis. 61(3) : 207-214

Warhdani W, Sumarwan U, Yuliati LN. 2015. Pengaruh Persepsi dan Preferensi Konsumen terhadap Keputusan Pembelian Hunian Green Product. Jurnal Manajemen dan Organisasi. 6(1) : 45-63 